\title{
Benefits of Project Management at Lean Manufacturing Tools Implementation
}

\author{
Tatyana A. Suetina ${ }^{1}$, Mikhail Y. Odinokov ${ }^{1} \&$ Dinara M. Safina ${ }^{1}$ \\ ${ }^{1}$ Kazan (Volga Region) Federal University, Russian Federation \\ Correspondence: Tatyana A. Suetina, Kremlin str. 18, Kazan, 420008, Russian Federation. E-mail: \\ science-kfu@mail.ru
}

Received: June 15, 2014 Accepted: July 21, 2014 Online Published: September 28, 2014

doi:10.5539/ass.v10n20p62 URL: http://dx.doi.org/10.5539/ass.v10n20p62

\begin{abstract}
The given article is devoted to reviewing the features of projects focused on implementation of lean manufacturing tools at the industrial enterprises. The study purpose is the statement of need to implement transformations in the field of lean manufacturing introduction (Lean-transformations) in the form of projects. The article introduces a concept of lean production project (Lean-project), the particular projects possessing the special aspects to be taken into consideration in the course of their implementation at various enterprises. The article demonstrates the benefits of Lean-transformations at applying the methods of project management. The key distinction of such projects is their result to be received upon completion. The result of the investment projects completion is to put into place a product or a service. The result of Lean-projects implementation is the introduction of lean manufacturing tools at the industrial enterprises to consequently obtain cost-effectiveness and a number of competitive advantages. Thus, the investment projects and Lean-projects are different in their constituent elements the study of which will make possible to formulate a system view of lean manufacturing project implementation. The article in general is focused on combination of two potent methodological frameworks-Project Management and Lean Manufacturing, each of which provides a means of obtaining significant benefits at their expert implementation and use. Combination of these is urged to provide multiplicative effect in the course of putting into practice the transformations at the industrial enterprises. However, to achieve the due effect it is necessary to be guided by the peculiar features of lean manufacturing projects what will necessarily call forth the correction of lean manufacturing methodological framework and derogation from stringent requirements of Lean Thinking concept.
\end{abstract}

Keywords: project management, lean production, lean thinking, lean manufacturing project (lean-project), transformations by means of lean manufacturing tools (lean-transformations)

\section{Introduction}

Lean Thinking concept existing over a number of decades far back became ingrained in our life. Russia accomplishes her first steps towards drawing on the researchers' best practices of a production system based on Lean Manufacturing concept. The books by James Womack and Daniel Jones devoted to the main tools and methods of the concept implementation enjoy the great popularity in Russia (Womack, 2003); (Womack, 2013). The core of the concept lies in scrutinous and sequential exclusion of losses within the process of products manufacture reducing thereby the time interval between the point of making a customer's order and the date of payment receipt.

A vast methodological framework proposed by the Lean Manufacturing researchers is intended to provide significant competitive advantages to the enterprises (Fakhrutdinova, 2014). However, a simple overlapping of Toyota Production Systems-TPS on other enterprises' manufacturing systems is not at all able to make provision for high level of efficiency. In such event, imposition of the enterprise's problems and the difficulties of adoption takes place. The developer of Toyota Production System, Taiichi Ohno, cautions against slavish imitation of foreign experience and underlines the necessity to develop an own system with a view to the enterprise's peculiar features and the working environment (Ohno, 2012). To successfully implement such system it is not enough to know how to apply it but it is necessary to thoroughly comprehend why it should be used (Hobb, 2007).

The experience of lean manufacturing implementation in Russia cannot be called unconditionally successful. Most often it is connected with putting lean manufacturing tools into practical use in pilot production areas being 
only a part of produce manufacturing chain. At the same time the losses eliminated on one manufacturing site turn to be negligible as compared to those existing on other work sites. According to the algorithm proposed by James Womack and often used in the course of lean manufacturing implementation, one of the determining factors of its prosperous accomplishment is to follow the slogan: to begin transformations wherever possible being not involved with strategic issues (Womack, 2003). But this way of introduction most often brings to randomness of realized reformations in view of paying less attention to their goals and possible results. The efficient tactics cannot be provided in the absence of clearly defined implementation strategy.

For improvement of the effectiveness in carrying out the reformations as pertaining to lean manufacturing tools it is necessary to raise the level of general office administration, to lay down measurable and achievable aims, to provide integrated nature of transformations not bringing the randomness in the process. Fulfillment of all these conditions will make provisions for applying the project management methodological framework in the course of reformations. Project Management has proved itself as the universal approach to highly-efficient attaining the goals of various nature and scale. Nowadays project management exists in the form of the universal methodological framework elaborated to a high standard and defining all aspects of the objective achievement process (PMI, 2013). At present the transition to the International Standard of Project Management from the series of International Organization for Standardization, ISO (Panasyuk, 2014) which may be used in organizations of any type for any projects independent from their scale, complexity and duration. Russia possesses its own experience of project management developed by Ivan Mazur and Vladimir Shapiro (Mazur et al., 2014), and some national standards based on the norms developed by the American Institute of Project Management (Project Management Institute, PMI) (PMI Moscow department, 2004). The vast experience of project management is able to serve the good turn at adaptation of lean manufacturing tools.

\section{Methods}

A part of tools can be implemented discretely but some organizations such as production line shops can be realized solely at distinct coordinating of all subdivisions involved in value engineering. That is why the renovations of this type require complex examination of enterprises and forming the strategy of implementation aiming at achievement of clearly defined measurable targets.

It makes sense to apply project approach at realizing transformations in the course of lean manufacturing introduction. For this purpose it is wise to begin with elaborating a program of renovations (Lean-program) as the complex of interrelated projects aimed at lean manufacturing principles adoption throughout the whole enterprise. The project comprising the complex of measures directed to elimination of certain losses in a certain subdivision with the help of lean manufacturing tool introduction we shall call Lean-project. (Suetina, 2012).

Lean-project allows eliminating concrete production losses and yields a technological result expressed in more economic and careful attitude towards all the resources, in particular, in the form of time saving. If this technological result can be interpreted in money terms its result acquires economical - technological character. The problem is in the fact that only the result of all Lean-projects within the frames of one technological chain including realization of output can be interpreted in monetary form. Otherwise, the economic result of Lean-project remains to be virtual. Thus, it is a reflection of the fact that the Lean-program has the real economic substance and economic feasibility.

Lean-projects possess their own peculiarities and features making them distinctive of other projects and hereupon require correction of project management methods and application of certain specialized procedures being not recorded in the standards (Suetina, 2013).

One of the main difficulties occurs at laying down the aims of lean manufacturing project since the project approach implies certain, achievable and measurable goals making possible to state completion of the project or the extent of their accomplishment. But in accordance with lean manufacturing concept lean- transformations cannot be accomplished: they must be carried out continuously and universally (Shingo, 2007). If Lean-projects come in the part of the enterprise Lean-program hierarchy structure, then they can have intermediate objectives being concrete and achievable, and the Lean-program itself can have continuous character permitting to initiate other projects when implementing one of them. The goal of the Lean-project in this case will be expressed in certain amount of losses to eliminate which in a certain subdivision it is possible with the help of some lean manufacturing tools introduced therein. In such a case one gets a possibility not only to supervise the course of Lean-project but clearly define the moment of its accomplishment.

To determine Lean-projects goals and feasibility it is possible to use value stream mapping (VSM) (Rother, 2006); (Jones, 2002). VSM of starting conditions ("as it") and desirable state ("as to be") are the best substantiation of the need to implement this or another renovation in the field of lean manufacturing. The quantity 
of losses that can be eliminated in the process of Lean-projects execution and estimated based on the value stream mapping appears to be the best method of expressing its goals. In this case they bear the achievable and measurable character what is very important at managing of any object or process.

The possibility to determine clearly defined success criteria of Lean-projects which can allow judging of their execution quality is also extremely important. In the quality of Lean-projects success criteria it is possible to use performance targets of value stream mapping for instance, the stream efficiency representing the ratio of value addition time to order execution time expressed in percentage. The time of value addition is the time when the value is added to a product within its processing. The time of the order execution is the full time of the value passing through the stream, from input to output. Depending on the features and quality of the production process the stream efficiency after Lean- project accomplishment can grow in tens of times.

\section{Results}

Application of project approach at managing the process of lean manufacturing tools introduction is capable to give considerable advantages. These advantages are summarized in Table 1 according to a process model of project management. (Pinto, 1998); (PMI, 2013).

Table 1. Advantages of project management at implementing of lean manufacturing tools

The stage of lean
$\begin{aligned} & \text { manufacturing } \\ & \text { implementation }\end{aligned}$

\begin{tabular}{|c|c|}
\hline & $\begin{array}{l}\text { The possibility to use achievable and measurable goals and the project } \\
\text { accomplishment success criteria based on the projects initiation according to value } \\
\text { stream mapping (VSM). }\end{array}$ \\
\hline $\begin{array}{l}\text { Initiation of lean } \\
\text { manufacturing project }\end{array}$ & $\begin{array}{l}\text { The possibility to use Lean-projects hierarchy structure and forming on its ground a } \\
\text { complex renovation program making possible to estimate possible realistic } \\
\text { economic effect from the complex realization. }\end{array}$ \\
\hline & $\begin{array}{l}\text { Managerial accounting system implement continuous transformations with the help } \\
\text { of Lean- program planning by method of "arriving wave" (Mazur et al., 2014), } \\
\text { what complies with the principles of continuous improvement Kaizen (Shingo, } \\
2007) \text {. }\end{array}$ \\
\hline $\begin{array}{l}\text { Lean manufacturing } \\
\text { project planning }\end{array}$ & $\begin{array}{l}\text { Application of clearly defined planning algorithm based on the main and auxiliary } \\
\text { planning processes. Construction of the plan of measures and diagram schedule of } \\
\text { their implementation with due regard to necessary resources and cost. }\end{array}$ \\
\hline $\begin{array}{l}\text { Execution and control of } \\
\text { Lean manufacturing } \\
\text { project }\end{array}$ & $\begin{array}{l}\text { Provision with work schedules complying with frequency of accounting and } \\
\text { control. Assurance of managerial accounting system proper functioning. }\end{array}$ \\
\hline $\begin{array}{l}\text { Lean manufacturing } \\
\text { project analysis }\end{array}$ & $\begin{array}{l}\text { The possibility to analyze the course of the project execution using special methods } \\
\text { within the frames of project methodology including Earned Value (Earned Value } \\
\text { Method) (Mazur et al., 2014; PMI, 2013). Forming time and cost borders for } \\
\text { achievement of lean manufacturing goals. }\end{array}$ \\
\hline $\begin{array}{l}\text { Lean manufacturing } \\
\text { project management }\end{array}$ & $\begin{array}{l}\text { Raising the level of the implementation project manageability and of the general } \\
\text { level of management and culture at the enterprise. Improvement of professional and } \\
\text { educational competence of the enterprise staff. }\end{array}$ \\
\hline $\begin{array}{l}\text { Accomplishment of Lean } \\
\text { manufacturing project }\end{array}$ & $\begin{array}{l}\text { Provision of the possibility to determine the termination point of the certain } \\
\text { Lean-transformations implemented in each certain subdivision in accordance with } \\
\text { the projects initiated. }\end{array}$ \\
\hline
\end{tabular}

\section{Discussion}

The suggestions set forward in the article are innovative. The authors are unaware of any discussions published in the main scientific magazines or any other scientific publications and devoted to the issues raised in the article. Some issues under examination were touched on in the works of the given article co-author (Suetina, 2012), (Suetina, 2014). The problems of project approach to performing Lean-transformations were also considered by Alexander Pyatkov (Pyatkov, 2009). 


\section{Conclusion}

As can be seen from the above the project management can turn to be useful at all the stages of transformations performance at the enterprise with the help of lean manufacturing tools. The utilization of the project management will reduce the randomness of tools introduction and will make possible to enable the discipline bringing in the process orderliness and goal orientation. We can state with assurance that competent and professional combination of Project Management with the concept of Lean Manufacturing is capable to create synergetic effect and to increase many fold the effectiveness of renovations. But it should be born in mind that Lean-manufacturing projects have certain peculiarities imposing the special requirements at using the project management methods and that to effectively apply the suggested methods it is necessary to have a balanced and proper functioning system of management accounting.

\section{Summary}

For a great many of enterprises only beginning to acquire the concept of Lean Manufacturing the process of its implementation appears to be rather difficult. Facing the problems many enterprises become disappointed in the concept and refuse to continue its further adoption. Application of the project framework in view of the features described in the given article must play the part of the implementation efficiency multiplier and enable the number of advantages, in particular, normalizing the implementation process, providing the meeting of deadlines and the cost of renovations introduction, effective allocating of the resources and involving all the enterprise personnel therein.

Rich experience gained in the sphere of Lean Manufacturing and Project Management implementation is worth studying. The issues of their combined use with the analysis of their points of contact and divergence also deserve examination. The given article is the first in the series of works planned to be published with a view of various aspects in Lean manufacturing projects management.

\section{References}

A Guide to the Project Management Bode of Knowledge. (5th ed.). (2013). Newtown Square: Project Management Institute.

A Guide to the Project Management Bode of Knowledge. (1996). Newtown Square: Project Management Institute.

A Guide to the Project Management Body of Knowledge. (Liberzon VI ed.). (2004). Moscow: PMI.

Fakhrutdinova, E., Severyanov, O., Shigabutdinov, A., \& Fakhrutdinov, R. (2014). The crisis of 1998 in Russia: Political intervention and its implications. Life Science Journal, 11(6s), 442-447.

Hobbs, D. P. (2004). Lean manufacturing implementation a complete execution manual for any size manufacturer. Moscow: J. Ross Pub.

Jones, D., \& Womack, J. (2002). Seeing the whole: Mapping the extended value stream. S.1.: LEI

Karasik, E., Yagudin, R., Leukhin, A., \& Zagidullina, V. (2014). Improvement of social policy towards the disabled in the Russian Federation. Life Science Journal, 11(6s), 478-481.

Kirshin, I. (2014). Modeling the long-term trend of accumulation of knowledge. Life Science Journal, 11(6s), 482-486.

Mazur, I., Shapiro, V., \& Olderogge, N. (2014). Project management. Moscow: Omega-L.

Ohno, T. (2012). Taiichi Ohnos Workplace Management: Special 100th Birthday Edition. New York: McGraw Hill.

Panasyuk, M., Pudovik, E., \& Sabirova, M. (2014). Problems of labor market of modern Russia in conditions of stable economic growth. Life Science Journal, 11(6s), 487-489.

Pinto, J. (1998). Project Management. San Francisco: Jossy-bass Inc.

Pyatkov, A. (n. d.). Project approach to Lean transformation and not only. LeanZone.ru. Retrieved May 23, 2014, from http://www.leanzone.ru/index.php?option=com_content\&view=article\&id=254:proektniy-podhoddlya-lean-preobrazovaniy\&catid $=38 \&$ Itemid $=90$

Rother, M., \& Shook, J. (2006). Learning to see: Value stream mapping to create value and eliminate muda (2nd ed.). Moscow, Russia: Lean Enterprise Institute.

Safiullin, L., Novenkova, A., Safiullin, N., \& Ismagilova, G. (2014). Prospects of small business in Tatarstan. Life Science Journal, 11(6s), 396-399. 
Shingo, S. (2007). Kaizen and the Art of Creative Thinking-the Scientific Thinking Mechanism. New York: PCS Inc. and Enna Products Corporation.

Suetina, T. (2013). Features of Projects Lean Production. Kazan, Russia: Herald Kazan State Technical University.

Suetina, T., \& Makhteeva, E. (2013). Lean-Program as the Way of Realizing Lean-Changes on Enterprise. Retrieved June 20, 2014, from http://www.sovman.ru/all-numbers/archive-2012/december2012/item/ 137-lean-programm-as-a-method-of-managing-lean-changes-in-the-company.html

Womack, J., \& Jones, D. (2003). Lean Thinking: Banish Waste and Create Wealth in Your Corporation (Revised and Updated). New York: Free Press.

Womack, J., \& Jones, D. (2013). Lean Thinking: Banish Waste and Create Wealth in Your Corporation (Revised and Updated). Translation from English. Moscow: Alpina Business Books.

\section{Copyrights}

Copyright for this article is retained by the author(s), with first publication rights granted to the journal.

This is an open-access article distributed under the terms and conditions of the Creative Commons Attribution license (http://creativecommons.org/licenses/by/3.0/). 